Проблемой глобального рынка морской торговли остается дисбаланс капитальных вложений по отдельным типоразмерным группам флота. Судоходные компании, не имеющие инвестиционных ограничений, формируют активные инвестиционные проекты на основе загрузки конкурентных по лидерству затрат судостроительных мощностей, что демонстрирует статистика портфеля заказов 2006 - 2014 годов. Вследствие этого формируется существенное отставание прироста финансовых результатов и наблюдается общее (среднее) падение нормы прибыли. Последующее выравнивание достигается в основном вследствие ухода в субстандартный сегмент судовладельцев и операторов с ограниченным доступом к инвестиционным ресурсам.

Выводы. Вследствие разномасштабных трансформационных процессов в структуре морской транспортной индустрии постоянно изменяется положение отдельных морских держав. Именно поэтому возрастает значение принятия и реализации активной морской транспортной политики государства флага.

$$
\text { К сожалению, структура }
$$

государственного управления в Украине построена на прямом вмешательстве ведомств в хозяйственную деятельность предприятий. Именно поэтому предпринимательские структуры, работающие вне пределов прямого административного регулирования, более эффективно реализуют инвестиционные проекты. Это подтверждает ТИС и «Нибулон» по сравнению с рядом расположенными портами Южный и Николаев. Фактически реализуется принцип стимулирования на основе вознаграждения за наиболее эффективные результаты формирования потенциала и его использования, с учетом закономерностей развития глобального рынка морской торговли и его структуризации.

\section{СПИСОК ЛИТЕРАТУРЫ:}

1. Антикризисное управление в торговом судоходстве : учебник / Н.Н. Примачева, Е.В. Сенько, Т.И. Фрасинюк ; под общ. ред. Н.Т. Примачева ; НАН Украины, Ин-т пробл. рынка и экон.-эколог. исследований. Одесса : ИПРЭЭИ НАНУ, 2015. - 306 с.

2. Review of Maritime Transport, 2014 Report by the UNCTAD

secretariat //United Nations New York and Geneva: 2014 - 184 p.

3. Дамодаран А. Инвестиционная оценка. Инструменты и техника оценки любых активов./ Пер. с англ. - М.: Альпина Бизнес Букс, 2004. $1342 \mathrm{c}$.

4. Самуэльсон П. А. Экономика / П. А. Самуэльсон, В. Д. Нордхаус; пер. с англ. - М.: И. Д. Вильямс, 2007. - 1360 с.

5. Сломан Дж. Экономикс / Дж. Сломан; пер. с англ. под ред. С. В. Лукина. - [5-е изд.]. СПб.: Питер, 2005. - 832 с.

6. Боди 3., Мертон Р. Финансы. пер. с англ. - Изд-во: Вильямс, 2007. - 592 с.

7. Моросини П., Стеджер У. Управление комплексными слияниями. - Днепропетровск: Баланс Бизнес Букс, 2005. - 304 с.

8. Портер М. Конкуренция. - М.: 2005. $-608 \mathrm{c}$

Рецензент д.э.н., профессор ОНМА Примачев Н.Т. Эксперт редакционной коллегии к.э.н., дочент УкрГУЖТ Полякова Е.Н.

\title{
ПРИВАТНО-ДЕРЖАВНЕ ПАРТНЕРСТВО - КРОК ЗАЛІЗНИЧНОЇ ГАЛУЗІ ДО СОЦІАЛЬНОЇ ВІДПОВІДАЛЬНОСТІ
}

\author{
Шкуліпа Л.В., к.е.н., доцент (НАСОА)
}

У статті розкрита практична значимість сочіальної відповідальності на підприємствах залізничного транспорту, реалізачія якої можлива за допомогою приватно-державного партнерства в період проведення структурних змін. Розглянуто вплив національної стратегії соиіально-відповідального бізнесу (СВБ) на залізничну галузь, а також наведені пропозиції щодо 
розширення меж співробітництва підприємств залізничного транспорту з вітчизняними та міжнародними організаціями. Зокрема, в період проведення змін аналіз сильних та слабких сторін залізничної галузі показав необхідність пошуку нових методів досягнення сочіальної відповідальності на підприємствах залізничного транспорту, таких як вступ до Глобальної мережі ООН, Украӥнського союзу промисловців та підприємців (УСПП).

Ключові слова: система соціальної відповідальності на підприсмствах залізничного транспорту (ССВЗТ), партнерство, соціально-відповідальний бізнес (СВБ), національна стратегія, сталий розвиток, УСПП

\title{
ЧАСТНО-ГОСУДАРСТВЕННОЕ ПАРТНЕРСТВО - ШАГ ЖЕЛЕЗНОДОРОЖНОЙ ОТРАСЛИ К СОЦИАЛЬНОЙ ОТВЕТСТВЕННОСТИ
}

\author{
Шкулипа Л.В., к.э.н., доцент (НАСОА)
}

B статье раскрыта практическая значимость социальной ответственности на предприятиях железнодорожного транспорта, реализация которой возможна с помощью частногосударственного партнерства в период проведения структурных изменений. Рассмотрено влияние нациионльной стратегии социально-ответственного бизнеса (СОБ) на железнодорожную отрасль, а также приведень предложения по расширению границ сотрудничества предприятий железнодорожного транспорта с отечественными и международными организациями. $B$ частности, в период проведения изменений анализ сильных и слабых сторон железнодорожной отрасли показал необходимость поиска новых методов достижения социильной ответственности на предприятиях железнодорожного транспорта, таких как присоединение к Глобальной сети ООН, Украинского союза промылиленников и предпринимателей (УСПП).

Ключевые слова: система социальной ответственности на предприятиях железнодорожного транспорта (ССОЖТ), партнерство, социально-ответственный бизнес (СОБ), национальная стратегия, устойчивое развитие, УСПП

\section{PUBLIC-PRIVATE PARTNERSHIPS - A MOVE THE RAILWAY SECTOR TO SOCIAL RESPONSIBILITY}

\author{
Shkulipa L.V., Ph.D., associate professor \\ (National Academy of Statistics, Accounting and Auditing)
}

The article deals with the practical importance of the social responsibility of enterprises of railway (SRER), the implementation of which is possible with the help of public-private partnerships in the period of structural change. Consideration is the impact of a national strategy of socially responsible business (SRB) for the rail industry, and also proposes to expand the boundaries of railway cooperation with domestic and international organizations. Namely, in the period of the change analysis of the strengths and weaknesses of the railway sector has shown the need to find new methods of achieving social responsibility of enterprises of railway, such as joining to the Global Network UN, to the Ukrainian Union Industrialists and Entrepreneurs (UUIE). National strategy of socially responsible business targets just on the rail sector cooperation with the private sector, state and society that will accelerate the formation of social responsibility in enterprises of railway, strengthening the position of the field in the transport market and entry of competitive appeal. That is the proper implementation of the National Strategy for CSR in Ukraine depends on implementation the main socially responsible tasks to of rail transport: at the economical level to provide low competitive advantages, will be increased access to capital and the market will increase the volume of passengers and freight transport, will operating costs will be increased productivity and quality of human resources; at the social level - will be increased standards of living railway employees; at the ecological - will be increased level of environmental safety, efficiency and careful use of natural resources; in a partnership - will to promote cooperation with the business will make it possible to protect national producer railway rolling stock.

Keywords: social responsibility of enterprises of railway (SRER), partnership, socially responsible business (SRB), national strategy, sustainable development, UUIE 
Постановка проблеми та ї̈ зв'язки 3 науковими чи практичними завданнями. Актуалізація питання соціальної відповідальності набирає широкого розмаху на українському бізнес-просторі. Взаємодія підприємств між собою дозволяє обмінюватися досвідом та знаннями у сфері відповідальності за екологічні, соціальні та економічні наслідки перед суспільством. Подальший розвиток різних форм партнерства дозволить вийти на рівень сталого розвитку України. У цьому повинен приймати участь i залізничний транспорт як ядро національної транспортної системи, яке забезпечує країну потужними вантажними та пасажирськими перевезеннями.

Аналіз останніх досліджень $i$ публікацій. В цілому (поза межами залізничного транспорту) розвиток та впровадження соціальної відповідальності розглядалися багатьма науковцями і бізнес-консультантами, такими як: А. Керолл, Ф. Котлер, Н. Лі, А. Маквильямс, М. Портер. Питання щодо впровадження принципів соціальної відповідальності досліджували А.О. Харламова, Л. П. Петрашко, О. Лазоренко, Р. Колишко, М. Саприкіна, В.К. Грищук, О.П. Гогуля, І.П. Кудінова, Н.А. Кричевський, С.Ф. Гончаров та багато інших. Однак у сфері надання транспортних послуг, співробітництва транспортних компаній, а також підприємств залізничного транспорту система соціальної відповідальності розглядалася дуже вузько серед невеликої кількості науковців-практиків у досліджуваній галузі.

\section{Виділення}

невирішених

частин

загальної проблеми. Зокрема, постійний аналіз вітчизняних публікацій у досліджуваній галузі засвідчує гостру практичну необхідність формування системи соціальної відповідальності на підприємствах залізничного транспорту (далі - ССВЗТ), теоретичні питання якої частково розкрито в працях А. Брайковської [11], Ю. Бурлакової [8], О. Ворони [7], В. Коломієць. Так, особливості оцінки рівня соціальної відповідальності залізничного транспорту, перелік показників оцінки, іï принципів, а також розкриття методичних основ складання соціального звіту залізничного транспорту розглядалися в працях О. Вороною; виявлення впливу основних напрямів соціальної відповідальності на конкурентоспроможність операторів залізничного транспорту А. Брайковською [11]. Широке коло питань, пов'язаних 3 визначенням показників ефективності та оптимальної структури управління залізничним транспортом, пошуку моделей розвитку знайшло своє відображення у працях таких науковців, як: Ю. С. Бараш, М.В. Макаренко,

О. М. Ложачевська, Ю. М. Цвєтов. Але здебільшого праці науковців мало стосувалися питань розширення соціальної відповідальності та шляхів іiі впровадження у практичну діяльність галузі. \begin{tabular}{lccr}
\multicolumn{2}{c}{ Враховуючи } & власні & попередні \\
дослідження & щодо & актуалізації & питання \\
соціальної & відповідальності & в & період
\end{tabular} реструктуризації залізничного транспорту [12] та результатів проведеного SWOT-аналізу щодо доцільності проведення реструктуризації [13], було визначено сильні та слабкі сторони галузі, а також можливості (шанси) та загрози іï функціонування. До однієї із слабких сторін належав пункт «недосконалий розвиток у приватно-державному партнерстві». Саме це послугувало у формуванні даної мети статmі, a саме: віднайти шляхи реалізації головних аспектів соціальної відповідальності на підприємствах залізничного транспорту за допомогою приватно-державного партнерства, які залишилися неохопленими до теперішнього часу.

\section{Викладення основного матеріалу} дослідження. Залізничне підприємство, як i будь-яке підприємство, має властивість взаємодіяти у внутрішньому та зовнішньому напрямках. Внутрішній напрямок полягає у взаємовідносинах в середині підприємства, зокрема 3 відокремленими структурними підрозділами, а зовнішній - 3 іншими підприємствами, організаціями, галузями, державою тощо. Такі відносини регулюються власними стійкими нормами, стандартами своєї діяльності, існуючими прикладами поведінки, властивими виключно залізничній галузі $[6$, с. 9].

Саме від взаємодії залізничної галузі 3 приватним сектором, державою та суспільством визначаються темпи формування ССВЗТ, зміцнення позицій галузі на транспортному ринку та набуття конкурентної привабливості.

Взаємодія бізнесу, держави та суспільства визнана необхідною не тільки для залізничної галузі - на державному рівні було вирішено затвердити ефективне партнерство бізнесу, влади та суспільства (рис. 1) в Концепції національної стратегії соціальної відповідальності бізнесу в Україні (обговорено на XIII з'їзді УСПП у грудні 2011 р., взято урядом до уваги та направлено на розгляд за дорученням Прем'єр міністра України № 7449/1/1-12 від 25.02.2012 р.), метою якої $\epsilon$ створення підгрунтя (як комплексу норм, правил, 
окремих організаційних механізмів) та України, зростання суспільного добробуту та сприятливих умов для інтеграції СВБ у вирішення питань, визначених у національних діяльність компаній задля сталого розвитку програмних документах [4].

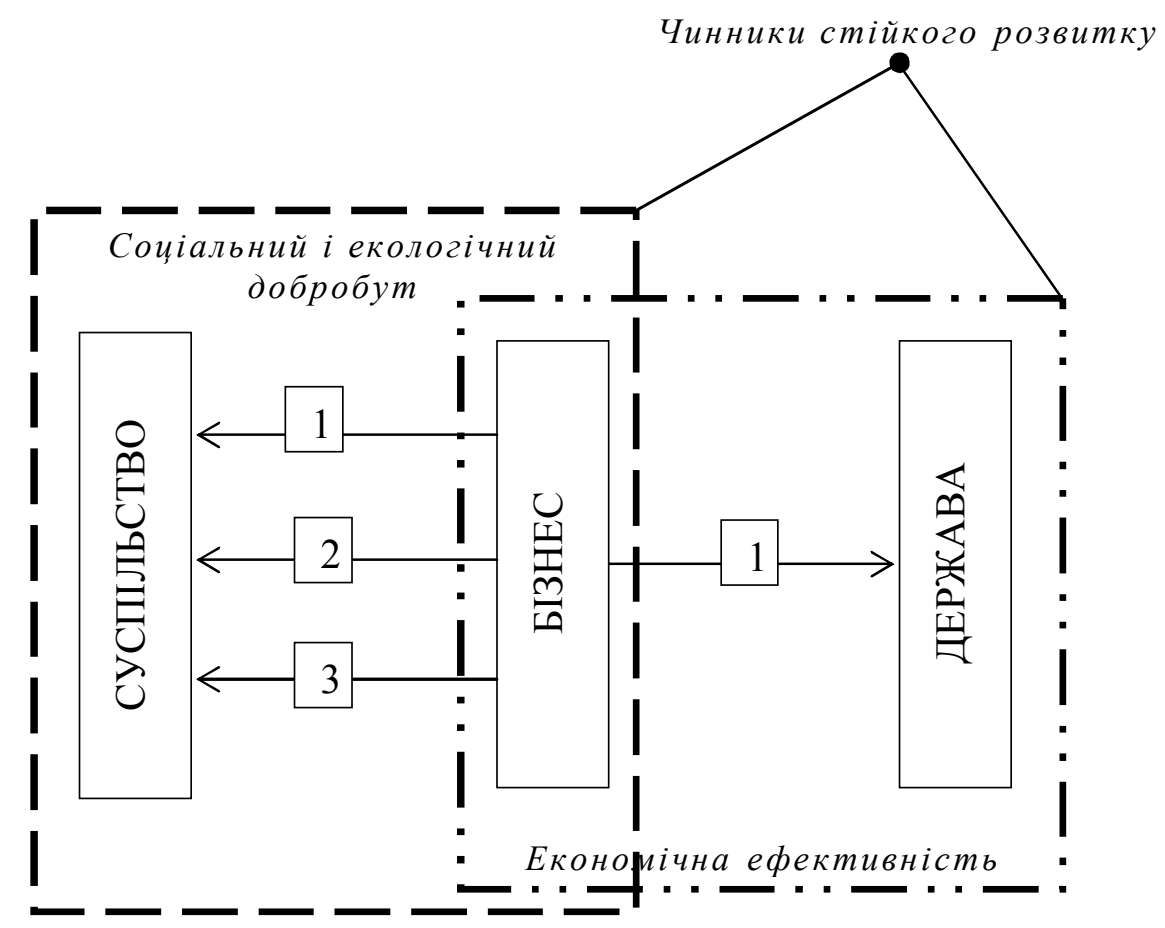

1 - дотримання законодавчих зобов'язань та галузевих стандартів

2 - мінімізачія або усунення негативного впливу, управління ризиками

3 - посилення позитивного впливу та створення цінностей через інновації, інвестиції та партнерство

Рис. 1. Кониепиія національної стратегії СВБ в Україні

Джерело: власна розробка.

В одних країнах така стратегія інтегрована в громадську політику (Данія, Франція, Фінляндія, Швеція), в інших соціально відповідальні практики $є$ виключно прерогативами компаній (Греція, Ірландія, Нідерланди, Словенія). В Європейському Союзі основна роль СВБ полягає у підтримці сталого розвитку компаній, що призводить до покращення ситуації на ринку праці, а також якості продуктів i послуг, що надаються компаніями (Комюніке Європейської Комісії, 2006). Країни СНД також зробили внесок у розвиток СВБ, розробивши та затвердивши міжнародний стандарт «Социальная ответственность организации. Требования. $\mathrm{CSR} / \mathrm{KCO}-2008 »$.

Для бізнесу соціальна відповідальність означає «досягнення комерційного успіху засобами, які передбачають дотримання моральних цінностей та повагу до людей, спільнот і навколишнього середовища» [5].
Для держави розвиток соціальної відповідальності бізнесу сприятиме розбудові партнерства між приватним та державним секторами в межах реалізації загальнодержавних стратегій соціально-економічного розвитку. В Україні підтримка держави необхідна для підкреслення важливої етичної i соціальновідповідальної поведінки як компаній в загалом, так і на підприємствах залізничного транспорту.

3 державною підтримкою український соціально-відповідальний бізнес безперечно матиме можливість захистити вітчизняного виробника, розширити виробництво, створити нові робочі місця.

Німецькі підприємці зуміли зробити так, щоб їх думка була вагомою у прийнятті важливих державних рішень [1, с. 9].

Для суспільства СВБ дозволить більшості компаній посилити відповідальне ставлення до своїх співробітників, споживачів та інших зацікавлених сторін, підвищить можливість жити 
в екологічно-чистому середовищі та мати здоров'я.

Правильно впроваджена Національна стратегія СВБ в Україні (рис. 1) дозволить залізничному транспорту на економічному рівні забезпечити низку конкурентних переваг: ширший доступ до капіталу та ринку, більші обсяги пасажирських та вантажних перевезень, покращені процеси прийняття рішень та управління ризиками, економію операційних витрат, зростання продуктивності та якості, ефективну база людських ресурсів, міцну репутацію, більшу лояльність клієнтів; на соціальному рівні - підвищення рівня життя працівників залізничного транспорту; на екологічному - рівня екологічної безпеки, ефективності і бережливого використання природних ресурсів; на партнерському - сприяє співпраці з бізнесом, дасть можливість захистити національного виробника рухомого складу залізничного транспорту, знос якого складає $90 \%$.

На захист національного інтересу як найвищої суспільної, державної цінності, яку потрібно відокремлювати, відстоювати та звеличувати на внутрішньому бізнес-просторі, так і на зовнішньополітичній, економічній арені, став Український союз промисловців та підприємців (далі - УСПП), створений в 1992 році [2]. Це призвело до ряду позитивних змін у підприємницькій діяльності не лише в декларативному, а в конкретному прикладному сенсі. Нині його роль посилилася у складі Міжнародного конгресу промисловців і підприємців, куди входять близько 30 ділових союзів держав Європи та Азії. Крім того, нещодавно УСПП підписали Меморандум про партнерство та співробітництво 3 Кабінетом міністрів України [4].

Тому, присднання українських залізниць до УСПП пропонується у зв'язку 3 його розгалуженою інфраструктурою $з$ органами державної влади, партнерськими взаємовідносинами 3 вітчизняними промисловцями, бізнес-організаціями різних країн світу (Союз транспортників Росії, МКПП, Німецький союз промисловості, Французька бізнес-асоціація «Medef», Японська асоціація бізнесу «Кейданрен», Американсько-українська ділова рада, Російський союз промисловців і підприємців тощо). Також УСПП відстоює інтереси своїх членів та надає їм наступні послуги (табл. 1).

Таблиця 1

Перелік послуг, щзо надаються апаратом УСПП прямим колективним членам

\begin{tabular}{|c|c|}
\hline $\begin{array}{l}\text { № } \\
n / n\end{array}$ & Перелік послуг \\
\hline 1 & $\begin{array}{l}\text { Розробка, експертиза та супровід проектів нормативних актів, їх удосконалення та } \\
\text { захист правової бази галузі }\end{array}$ \\
\hline 2 & $\begin{array}{l}\text { Направлення до органів державної влади звернень, що відображають інтереси членів } \\
\text { УСПП, та відстеження реагування на них }\end{array}$ \\
\hline 3 & $\begin{array}{l}\text { Налагодження відносин з банківськими, науковими установами, консалтинговими } \\
\text { компаніями для розвитку власного бізнесу, пошук перспективного розвитку } \\
\text { діяльності. }\end{array}$ \\
\hline 4 & $\begin{array}{l}\text { Члени УСПП можуть брати участь у роботі міжнародних бізнес-форумів, діяльності } \\
\text { двосторонніх міжурядових комісій. }\end{array}$ \\
\hline 5 & $\begin{array}{l}\text { Соціально відповідальний бізнес, позитивний вплив } \text { наслідків діяльності на } \\
\text { суспільство і навколишнє середовище. }\end{array}$ \\
\hline 6 & $\begin{array}{l}\text { УСПП пропонує своїм членам систему корпоративної безпеки, яка допоможе у } \\
\text { випадку суперечок } 3 \text { недобросовісними партнерами i рейдерами, захистить від } \\
\text { бюрократичного тиску }\end{array}$ \\
\hline 7 & $\begin{array}{l}\text { Опрацювання комерційних пропозицій, що надходять від потенційних партнерів } \\
\text { членів УСПП }\end{array}$ \\
\hline 8 & $\begin{array}{l}\text { Участь у складі делегації УСПП у роботі бізнес-форумів, конференцій, в тому числі } \\
\text { міжнародних }\end{array}$ \\
\hline 9 & $\begin{array}{l}\text { Участь у заходах, що проводяться УСПП (круглі столи, наради, робочі засідання } \\
\text { тощо) }\end{array}$ \\
\hline 10 & Пошук для членів УСПП комерційних, ділових партнерів \\
\hline
\end{tabular}


Такий вступ дасть багато можливостей галузі як в розвитку економічної діяльності транспорту, так i y підвищенні його конкурентопривабливості.

В незалежній Україні першою бізнесорганізацією, яка взяла на себе захист прав та інтересів ділової громади, підтримки національного товаровиробника та просування його інтересів на зовнішні ринки, у серпні 1991 року стала Асоціація промисловості, будівництва, транспорту та зв'язку [1, с. 8]. То чому нині УЗ не відходить до УСПП?

«Тоді панували дух економічної єдності, щире прагнення допомогти один одному, врятувати коопераційні зв'язки» - пригадує почесний президент УСПП В.Г. Урчукін, який очолював Асоціацію в 1991-1996 рр. Так, дійсно, зберегти позитивну частину виробничої спадщини радянських часів - величезний промисловий та кадровий потенціал, коопераційні зв'язки та тісні торгівельні стосунки із зовнішнім світом не вдалося.

На сьогоднішній день маємо іншу картину: бізнес йде назустріч державі для вирішення різних питань. Наприклад, в 2011 р. зростання вантажних перевезень в Україні, 80\% рівень фізичного зносу рухомого складу призвели до нестачі близько 25 тисяч залізничних вагонів. Це спричинило затримку Укрзалізницею експорту зерна (понад 30 млн.тон від загального врожаю в 57 млн. тон), олійножирової продукції в країни СНД та Балтії.

Для вирішення цієї інфраструктурної проблеми УСПП виступив ініціатором підписання в лютому 2012 року Меморандуму про партнерство між УЗ та асоціаціями аграрного бізнесу, чим і дав змогу врегулювати конфлікт між перевізниками і експортерами с/г продукції. В результаті підписання створена Експертна робоча група розробила подальші ефективні методи державно-приватного партнерства для врегулювання дисбалансу між попитом i пропозицією на ринку вантажних перевезень та кардинального оновлення парку рухомого складу українських залізниць. Одним 3 таких методів став контракт на закупівлю щомісяця понад 10 напіввагонів, згідно якого у 2012 р. "Укрзалізниця" переходить на лізингову програму купівлі залізничного рухомого складу у вітчизняного виробника. В нагоді послугувало членство в УСПП Крюківського вагонобудівного заводу - найбільшого в СНД виробника залізничного рухомого складу, та Державного експортно-імпортного банку «Укрексімбанк» (член УСПП 3 06.2011p.), який визнав високу рентабельність в результаті вивчення ринку вітчизняних залізничних перевезень і погодився відкрити кредитну лінію для Дніпровської операторської компанії, яка займається вантажними залізничними перевезеннями.

Експертна рада й надалі продовжує працювати над питаннями додаткового фінансування для оновлення рухомого залізничного складу. А на сьогоднішній день Українська залізниця почала нарощувати свої фінансові показники, Укрексімбанк отримав надійного й прогнозованого партнера, а Крюківський вагонобудівний завод платоспроможного покупця. Більше того, даний проект дав новий імпульс для розвитку гірничометалургійної галузі України, продукцію якої в основному й перевозить Дніпровська операторська компанія.

Крім того, позитивними вважаються пропозиції та зауваження УСПП, що стосувалися врегулювання питання оподаткування ПДВ операцій з надання нерезидентами в оперативний лізинг (оренду) транспортних засобів, в тому числі рухомого складу залізничного транспорту, які, на жаль, були відхилені урядом. Це призводить до значних втрат конкурентних переваг вітчизняними підприємцями, які надають в оренду транспортні засоби (наприклад, рухомий склад виробництва Крюківського вагонобудівного заводу) [9].

Адже, існуючий Податковий кодекс України суттєво обмежує можливості компанії 3 надання послуг нерезиденту. Так, відповідно до п.186.3 Податкового кодексу: «Місцем постачання зазначених у цьому пункті послуг вважається місце, в якому отримувач послуг зареєстрований як суб'єкт господарювання або у разі відсутності такого місця - місце постійного чи переважного його проживання. До таких послуг належать: ... г) надання в оренду (лізинг) рухомого майна, крім транспортних засобів та банківських сейфів» [10, с. 18].

Оскільки відповідно до п.185.1

Податкового кодексу: «Об'єктом оподаткування $\epsilon$ операції платників податку 3: ...б) постачання послуг, місце постачання яких розташоване на митній території України, відповідно до статті 186 цього кодексу», операція 3 надання вантажного залізничного транспорту в оренду нерезиденту, всупереч економічної логіці, $\epsilon$ об'єктом оподаткування податком на додану вартість. Ситуація, що склалася, потребує негайного вирішення, оскільки істотні курсові коливання та непрозора тарифна політика ціноутворення на залізничному транспорті 
України вже призвела до ліквідації у 2010 р. 79 приватних власників залізничного складу та критичного показника дефіциту рухомого складу. Його подальше зростання призведе до неспроможності Укрзалізниці забезпечити необхідний обсяг вантажних залізничних перевезень та зростання ВВП, отже ситуацію треба негайно виправити.

Bce ж таки зусиллями УСПП, Інвестиційній вагонній компанії вдалося вирішити питання відшкодування податку на додану вартість, урегулювати з податківцями всі проблемні моменти, які виникали у процесі нашої роботи, а також внести свої суттєві пропозиції до Податкового й Митного кодексів $[7$, c. 31].

Інвестиційна вагонна компанія - друга в Україні за масштабами недержавна структура, яка має власний сучасний рухомий парк вантажних залізничних вагонів. За підсумками 2007 та 2010 років компанія отримала другу місце в номінації «Лідер галузі» за класифікатором видів економічної діяльності. Визначення кращих підприємств здійснювалося на основі обєктивних даних: обсяг реалізації, прибуток, продуктивність праці та середня заробітна плата. У власності компанії - 1906 залізничних вагонів, які вона надає у користування чи оренду. Оскільки Укрзалізниця не може сповна задовольнити потреби промислових підприємств України у вантажних залізничних перевезеннях, то послуги Інвестиційної вагонної компанії дуже затребувані.

У 2002 році на підприємстві спільно 3 німецькою фірмою Сіменс був створений чотиривісний вантажно-пасажирський електровоз змінного струму 3 асинхронним тяговим i допоміжним приводом, мікропроцесорною системою керування. Електровоз вмістив у себе кращі досягнення світового електровозобудування. Нині 18 таких електровозів експлуатуються на ПівденноЗахідній залізниці для ведіння прискорених пасажирських поїздів зі швидкістю до 160 км/год.

У зв'язку з тим, що залізниці України користуються постійним і змінним струмом, для можливості використання пасажирських поїзів без заміни електровозів на станціях стикування потрібні електровози подвійного живлення. Тому зараз завод виконує розробку нового восьмивісного двосекційного пасажирського електровоза подвійного живлення з асинхронним приводом типу ДС4, який дозволить водити пасажирські поїзди з 18-24 вагонів зі швидкістю до 200 км/год [10].

Сподіваємось, що створення таких електровозів виключить необхідність закупівлі імпортних машин, забезпечить створення нових робочих місць. До речі, вартість їх виготовлення в Україні буде значно меншою, ніж розробка і виготовлення за кордоном.

Укрзалізниця 2012 року отримала статус серед переможців номінації «Гордість нації», яку проводив УСПП у першому проекті «Профалангові української економіки. Будівельний комплекс. Енергозбереження» та відібрав кращі вітчизняні підприємства, які попри складні кризові часи зуміли втримати лідерство та здобути успіх у своїх галузях $[2$, с. 3].

Крім того, відмічається негативний момент в діяльності залізничного транспорту, починаючи 31995 року, Укрзалізниця ввела в практику масову подачу вагонів під навантаження на територію Венгрії та Словаччини. В результаті втрачено 90\% ринку, $30 \% 3$ яких вдалося повернути, але щорічні збитки України складають близько 21 млн.грн., а держбюджет недоотримує щорічно близько 4 млн. Тут потрібним також $є$ втручання та допомога УСПП [9].

Експерти УСПП вважають за необхідне зафіксувати в законодавчому плані, що державне підприємство самостійно розпоряджається ресурсами, які створюються за рахунок його виробничої діяльності, а також залученими кредитами й інвестиціями. Пропонується зробити ці ресурси не коштами бюджету, ними підприємство повинно розпоряджатися вільно й на свій розсуд з урахуванням відповідальності менеджерів, з урахуванням кон'юнктури. Тут про тендер i конкурс можна говорити, коли підприємство отримує бюджетні ресурси для реалізації оборонного замовлення, та й то 3 урахуванням певних умов. Дійсно, залізниці в цьому питанні також зв'язані по руках і ногах.

Ефективним партнерством для залізниці на міжнародному рівні пропонується приєднання до Глобальної мережі $\mathrm{OOH}$, членами якої $\mathrm{\epsilon}$ УСПП, Центр розвитку КСВ та багато інших успішних українських компаній. Вступ дасть змогу дотримуватися принципів ГД ООН у своїх соціальних звітах, які є пріоритетним показником переходу на рівень КСВ.

Фірми-члени мережі (наприклад, KPMG) допомагають компаніям у проведенні порівняльного аналізу з іншими представниками відповідних галузей на предмет визначення 
найкрашьої галузевої практики управління в розрізі принципів Глобального договору з метою підготовки планів удосконалення.

Для кращого розуміння бізнесу своїх клієнтів створюються групи 3 галузевої спеціалізації, які очолюють експерти 3 багаторічним досвідом роботи в таких галузях економіки: банківський та фінансовий сектор, фонди прямих приватних інвестицій, страхування, енергетика та природні ресурси, сталий розвиток, фармацевтична галузь, сільське господарство, споживчий сектор, інфраструктура, будівництво та нерухомість, телекомунікації та зв'язок, автомобільна промисловість, транспортний сектор i логістика, інновації та технології.

Висновки $\boldsymbol{i}$ перспективи подальших розробок. Таким чином, приватно-державне партнерство на сучасному етапі глобальної реструктуризації дозволить вийти залізничній галузі на конкурентний шлях та приблизить до соціальної відповідальності. Ефективна взаємодія 3 вітчизняними та міжнародними організаціями забезпечить використання капіталу у широкомасштабні національні та міжнародні інвестиційні проекти у галузь, розвиток персоналу, ефективну взаємодію із споживачами і навколишнім середовищем. Підтримка держави та бізнесу зможе дати базис в подальшому для сталого розвитку залізничного транспорту України, а також виступить гарантом екологічної та соціальної захищеності суспільства в цілому.

\section{СПИСОК ЛІТЕРАТУРИ}

1. Вісник УСПП, квітень 2012, 2(29) [Електронний pecypc]. - Режим доступу: http://www.uspp.org.ua/magazine.

2. Вісник УСПП, березень 2012, № 1(28) [Електронний ресурс]. - Режим доступу: http://www.uspp.org.ua/magazine.

3. Вісник УСПП, травень 2010, № 2(20) [Електронний ресурс]. - Режим доступу: http://www.uspp.org.ua/magazine.

4. Про державно-приватне партнерство: Закон України прийнятий Верховною Радою України від 01.07.2010 № 2404-VI [Електронний pecypc]. - Режим доступу: http://zakon2.rada.gov.ua/laws/show/2404-17.

5. Жиглей I.В. Бухгалтерський облік соціально відповідальної діяльності: теорія, методологія, організація : дис. ... доктора екон. наук: спец. 08.00.09 / Жиглей Ірина Вікторівна. Житомир, 2011. - 270 c.

6. Промышленное предприятие и его люди: проблемы социально-экономического поведения [Текст] / Под общ. ред. В.М. Вороны, Е.И. Суименко. - К.: Институт социологии НАН Украины, 2001. - 352 с.

7. Ворона О.В. Обгрунтування необхідності системи соціальної відповідальності залізничного транспорту для забезпечення його конкурентоспроможності / О.В. Ворона // Вісник Хмельницького національного університету. T.1. - № 4. - 2010. - C. 257-263.

8. Бурлакова Ю.М. Корпоративна соціальна відповідальність: внутрішнє спрямування [Електронний ресурс] / Ю.М. Бурлакова. - Режим доступу: http://www.rusnauka.com/5_PNW_2010/Economics/ 59062.doc.html

9. Вісник УСПП, жовтень 2011, № 1(28) [Електронний ресурс]. - Режим доступу: http://www.uspp.org.ua/magazine.

10.Вісник УСПП, вересень 2011, № 3(25) [Електронний ресурс]. - Режим доступу: http://www.uspp.org.ua/magazine.

11.Брайковська А. Соціальна

відповідальність як фактор конкурентоспроможності операторів залізничного транспорту в СС / А. Брайковська // Збір. наук. праць ДЕТУТ : Економіка і управління. - 2015. Вип. 31. - С. 54-63. - Режим доступу: http://nbuv.gov.ua/jpdf/

Znpdetut_eiu_2015_31_8.pdf

12.Шкуліпа Л.В. Соціально-відповідальна реструктуризація залізнич-ного транспорту в Україні як провідна детермінанта в ССВЗТ [Електронний ресурс]

Л.В. Шкуліпа // Зб. наук. праць ДЕТУТ. Економіка і управління. - 2012. - Вип. 21-22(1). C. 66-73. - Режим доступу: http://nbuv.gov.ua/jpdf/Znpdetut_eiu_2012_21-22(1)_9.pdf

13. Шкуліпа Л. В. Застосування SWOTаналізу для оцінки доцільності проведення реструктуризації на залізничному транспорті України [Електронний ресурс] / Л.В. Шкуліпа // Вісник соціально-економічних досліджень. - 2013. - Вип. 1. - С. 168-175. - Режим доступу: http://nbuv.gov.ua/j-

pdf/Vsed_2013_1_28.pdf

Рецензент д.е.н., доцент НАСОА Пилипенко О.I. Експерт редакційної колегії к.е.н., дочент УкрДУЗТ Токмакова І.В. 